\title{
VERBAL EXPRESSION OF PREPAREDNESS IN RETIREMENT PLANNING INTERVIEWS
}

\author{
Liudmyla Mahdysiuk \\ https://orcid.org/0000-0002-5304-933x \\ magdisyuk.lyudmila@vnu.edu.ua \\ Lesya Ukrainka Volyn National University, Ukraine
}

Halyna Tryhub

https://orcid.org/0000-0002-4455-5978

galya.trigub@vnu.edu.ua

Lesya Ukrainka Volyn National University, Ukraine

Tamara Duchiminska

https://orcid.org/0000-0002-3352-3188

duchiminska.tamara@vnu.edu.ua

Lesya Ukrainka Volyn National University, Ukraine

Anna Kulchytska

https://orcid.org/0000-0003-1350-6556

kulchucka.anna@vnu.edu.ua

Lesya Ukrainka Volyn National University, Ukraine

Larysa Zasiekina

https://orcid.org/0000-0001-8456-0774

Scopus Author ID: $\underline{57215414977}$

zasyekina.larisa@vnu.edu.ua

Lesya Ukrainka Volyn National University, Ukraine

Received June 8, 2020; Revised August 18, 2020; Accepted September 15, 2020

\begin{abstract}
Conceptualization of retirement requires interdisciplinary research, which is represented by psycholinguistic approach in the present paper. The study takes a first step to explore conceptualization of retirement by individuals with different levels of retirement preparedness. The study applies Psychological Preparedness for Retirement Questionnaire (Zasiekina \& Mahdysiuk, 2018) to assess levels of preparedness; semi-structured interviews to focus primarily on concerns related to planning postretirement period; Linguistic Inquiry and Word Count (LIWC) (Tausczik \& Pennebaker, 2010) to reveal psychological categories and explore conceptualization of retirement. By the end of the assessment, data had been collected from 117 workers who were at preretirement period. The sample was weighted by age and
\end{abstract}

(C) Mahdysiuk, Liudmyla; Tryhub, Halyna; Duchiminska, Tamara; Kulchytska, Anna; Zasiekina, Larysa, 2020.

This is an Open Access article distributed under the terms and conditions of the Creative Commons Attribution 4.0 International Licence (http://creativecommons.org/licenses/by/4.0) East European Journal of Psycholinguistics, 7(2), 190-200. https://doi.org/10.29038/eejpl.2020.7.2.mah 
occupation in order to improve its representative of the total population $22(18.8 \%)$ - university staff, teachers at colleges, $18(15.4 \%)$, nurses in kindergartens, 8 (6.6\%), healthcare staff, 18 $(15.4 \%)$, government officials, $28(23.9 \%)$, workers from private sector, $23(19.7 \%)$ lawyers. The final weighted sample includes $65.8 \%$ females, average age 54.52, (SD=6.21). The results indicate that $8.5 \%$ respondents have a low level of preparedness, $61.5 \%$ - a medium level of preparedness and $30 \%$ - a high level of preparedness. Interestingly, the highest percentage of categories of affect and positive emotions were observed in the group with a medium level of preparedness, whereas the highest percentage of categories cause,focus on present, and family were captured in the group with a high level of preparedness. Taken together, these results suggest that the high level of retirement preparedness is associated with active cognitive reappraisal of retirement as a period of family activities.

Keywords: preparedness for retirement, retirement planned interviews, conceptualization, psychological meaning.

Магдисюк Людмила, Тригуб Галина, Дучимінська Тамара, Кульчицька Анна, Засскіна Лариса. Вербальні маркери готовності до виходу на пенсію в інтерв'ю.

Анотація. Проблема концептуалізації виходу на пенсію вимагає міждисциплінарних досліджень, які представлені психолінгвістичним підходом у цій роботі. Праця є першим кроком на шляху вивчення концептуалізації виходу на пенсію особами з різним рівнем готовності до цієї події. У статті використано авторський опитувальник «Психологічна готовність до виходу на пенсію» (Засєкіна \& Магдисюк, 2018) для оцінки рівня таокї готовності; напівструктуровані інтерв'ю, спрямовані головним чином на проблеми, пов'язані з плануванням періоду після виходу на пенсію, українську версію комп'ютерної програми LIWC (Tausczik \& Pennebaker, 2010), щоб розкрити психологічні категорії та дослідити аспекти концептуалізації виходу на пенсію. Було зібрано дані від 117 працівників, які перебували у передпенсійному періоді. Вибірка була збалансована за віком та професією з метою покращення ï репрезентативністі від загальної сукупності: $22(18,8 \%)$ співробітника університетів, викладачів коледжів, 18 (15,4\%) медсестер дитячих садків, 8(6,6 \%) представників медичного персоналу, $18(15,4 \%)$ держслужбовців, $28(23,9 \%)$ працівників приватного сектору, 23 (19,7\%) юристів. Остаточна зважена вибірка включає 65,8 \% жінок, середній вік 54,52 (SD =6,21). Результати показують, що $8,5 \%$ респондентів мають низький рівень, $61,5 \%$ - середній рівень та $30 \%$ - високий рівень готовності. Цікавим видається те, що найвищий відсоток категорій афекту (affect) та позитивних емоцій (posemo) простежено в групі із середнім рівнем готовності, а найбільший відсоток категорій каузальності (cause), фокусу на теперішньому (present) та родини (family) здобула група з високим рівнем готовності підготовленості. Загалом, одержані результати дають змогу припустити, що високий рівень готовності до виходу на пенсію пов'язаний з активною когнітивною переоцінкою проблеми виходу на пенсію як один із періодів розвитку сім'ї.

Ключові слова: готовність до виходу на пенсію, інтерв'ю щуодо пенсійних планів, концептуалізація, психологічне значення.

\section{Introduction}

There is a growing body of literature that recognizes the importance of retirement preparedness since retirees have a number of psychological issues, notably loss of identity aligned with professional life (Osborne, 2012). Osborne (2012) argues that the main negative effects of preretirement period includes difficulties in decision making, decreased self-esteem and self-confidence, loss of meaning in identity, and death-anxiety. In contrast to loss of identity in retirees, there is much less information about constructing meaning of retirement by individuals with different levels of retirement preparedness. This indicates a need to 
understand the various meanings of retirement that exist among individuals in preretirement period. This study provides an important opportunity to advance the understanding of the main negative psychological issues aligned with retirement, and suggests psychological support for individuals in preretirement period.

The present article takes a first step to explore constructing meaning of retirement in individuals with different levels of retirement preparedness and examines the main difficulties in preretirement period, expressed verbally in retirement planning interviews.

Following Wang and Sci (2014), we conceptualize retirement as an individual's exit from the workforce, which accompanies decreased psychological commitment to and behavioral withdrawal from work (p. 211). The scholars suggest four main approaches to conceptualizing retirement from psychological perspective, particularly retirement as a decision-making, retirement as an adjusting process, retirement as a career development stage, and empirical operationalization of retirement.

Retirement as a decision making relates to informed decision making based on a deep knowledge about own resources, peculiarities of the current work and nonworking environment, particularly family and community-social settings. From decision making approach pension program should be planned early before old age, serving as a financial and social support for retirees. Planning retirement when individual is young and efficient at the workplace is very important for avoiding psychological comorbidities when time for retirement comes (Park, 2017). Pension program is developing as a result of retirement decision-making and accompanied by declining work activities and strengthening involvement in social and family life (Wang \& Schultz, 2010). Evidence consistently suggests that current life goal is a robust predictor of having a pension program and retirement decision making, which relate to retirement readiness (Atuti, 2020).

Adjustment approach views retirement as retirement transition and postretirement adaptation. Psychological peculiarities of transition to retirement relate to different stages, in particular retirement approaches, initial euphoria, some stress, dealing with adjustments to a new lifestyle, then settling down (Victor, 1994). All these stages are characterized by specific difficulties in retirees. Findings of other research indicate that perceived happiness in financial situation, being married, being female, having master or doctorate degree strongly predict retirement preparedness in retirement transition and postretirement adaptation (De los Santos, Labrague, \& Milla, 2019).

Retirement as a career development is considered at the individual, job, and organizational levels. The retirement at the individual learning is viewed as physical, and cognitive aging, on the one hand, and enriching experience and expertise, on the other hand. At the job level, retirement is examined as correspondence to technologies requirements. At the organizational level, retirement is assessed through the organizational climate, particularly age bias and discrimination. 
Empirical operationalization of retirement captures different dimensions of this period. Recent research points out that paid work hours, nature of the employment, and amount of pension/social security in post-retirement period should be considered as the main characteristics of heterogeneity of this period (Wang, Olson, \& Shultz, 2012).

Together, these studies indicate that there is no well-established approach to conceptualization of retirement process. Considering retirement from decision making, adjustment, career developmental and empirical approaches, preparedness for retirement and retirement planning are of crucial importance. As Wang and Schultz (2010) argue, an interdisciplinary research could summarize all different studies on psychological issues of retirement and conceptualize retirement for the perspective of its psychological consequences.

\section{Methods}

The psycholinguistics study as an interdisciplinary approach in our paper was chosen because it leads to deeper insight into constructing meaning of retirement in individuals with different levels of preparedness. Central to the entire discipline of psycholinguistics is the concept of meaning which leads to understanding the sense of retirement for individuals. Vygotsky (2014) points out that meaning is the act of cognitive generalization and communication, therefore, the meaning of retirement could indicate not only sense of retirement in individuals but their attitudes towards it, verbally expressed in their retirement planned interviews. The study applies questionnaire Psychological Preparedness for Retirement (Zasiekina \& Mahdysiuk, 2018). We approached 201 workers who were at preretirement period. The sample was weighted by age and occupation in order to improve its representative of the total population $22(11 \%)$ - university staff, teachers at colleges, $18(9 \%)$, nurses in kindergartens, 8 (4\%), healthcare staff, 18 (9\%), government officials, $28(14 \%)$, workers from private sector, $23(11 \%)$. The final weighted sample includes $66 \%$ females, average age 54.52, $(\mathrm{SD}=6.21)$

Forty questions were asked, beginning with the statement: "How often are you concerned about each of the following things regarding your preparedness to retirement?". For example, the fact that there are some physiological and mental changes aligned with aging. The participants had to think about their concerns related to forthcoming retirement, and were assessed with 40 items anchored from 0 to 3 , where $0=$ never, $1=$ rarely, $2=$ often, and $3=$ every time. The high scores are associated with level of preparedness. Inter-item reliability ( $\alpha$ Cronbach) was high (0.840). The study applies percentiles to identify the central tendency, and dispersion of a distribution, and differentiates three levels of retirement preparedness: low (0-46), medium (47-93), high (94-120), the maximum score in a composite scale $=120$.

The main objective of the study was to carry out semi-structured interviews with individuals in preretirement period, who had different levels of preparedness to retirement. We focused primarily on concerns broadly related to planning postretirement period. This category includes plans for certain activity, emotions 
and feeling towards this life period, drives for self-development and social interactions. Many individuals in our study reported their professional experience and achievements.

The study applies semi-structured interviews to provide psycholinguistic approach to explore constructing meaning of retirement in individuals with different levels of retirement preparedness. We audio-recorded and transcribed interviews. Transcriptions were analysed by the research team using the Linguistic Inquiry and Word Count (LIWC) (Tausczik \& Pennebaker, 2010) in Ukrainian version (Zasiekin et al., 2018). The LIWC analyzes the words and administer them according with the pre-defined categories of positive and negative emotions, motivation, thinking styles and social relationships. The present study examines the psychological meaningful categories as verbal expression of individual preparedness to retirement.

\section{Results and Discussion}

Figure 1 illustrates the distribution of participants considering low, medium and high levels of preparedness for retirement. It is apparent from this figure that very few participants $(8.5 \%)$ demonstrate a low level of preparedness for retirement, the greater part of participants $(61.5 \%)$ have medium level, and almost a third of participants $(30 \%)$ have a high level. It is apparent from this figure that very few individuals have no concerns about postretirement life and its possible goals. Almost one third of individuals often think about forthcoming period and plan their activity considering life changes.

Figure 1.

Distribution of individuals with different levels of preparedness for retirement

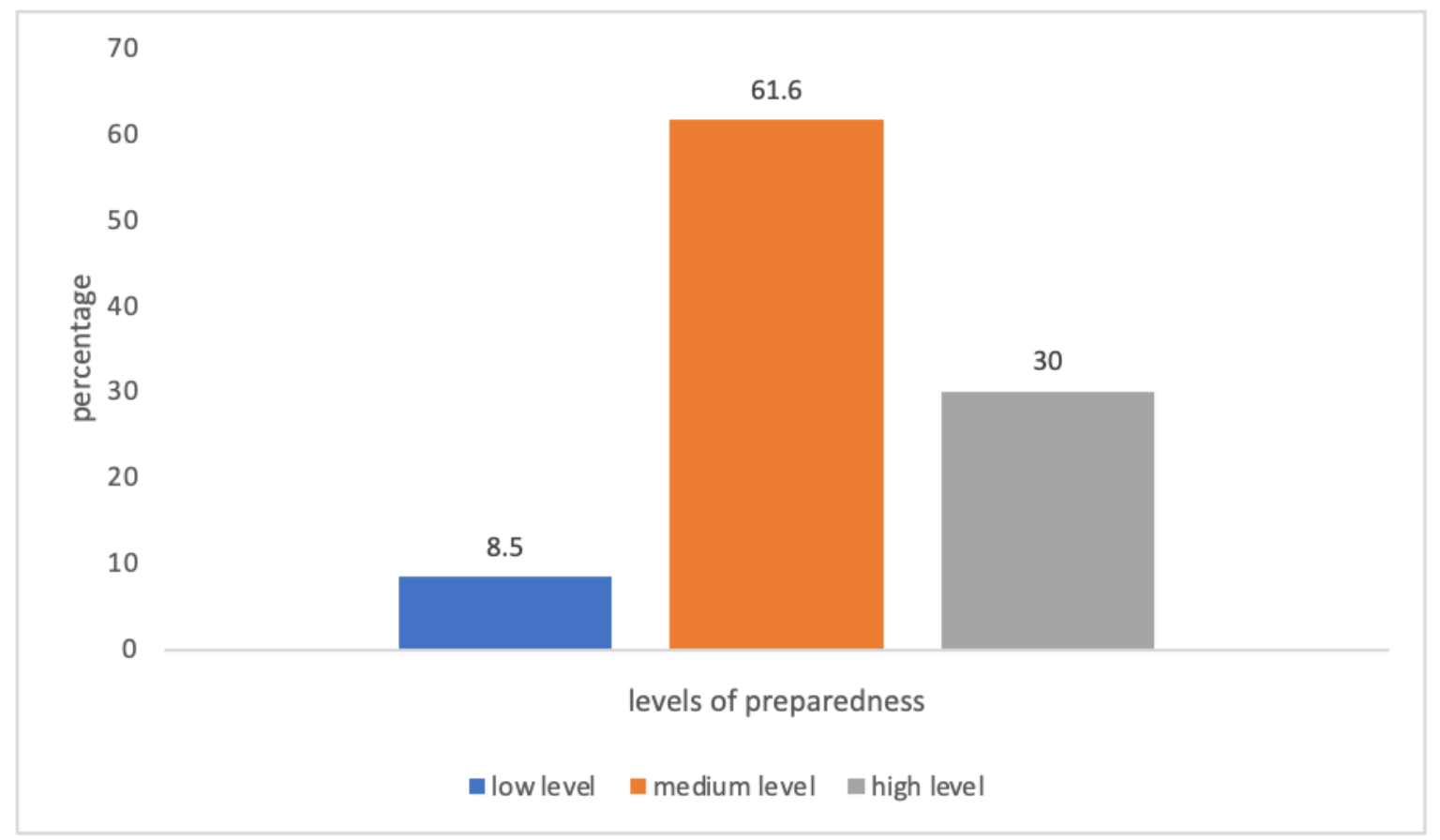


Table 1.

Categories in retirement planned interviews in individuals with different levels of retirement preparedness

\begin{tabular}{llll}
\hline Categories & FG 1, M (SD) & FG 2, M (SD) & FG 3, M (SD) \\
\hline I & $4.40(1.35)$ & $6.69(3.29)$ & $4.48(2.11)$ \\
Positive emotions & $0.89(0.18)$ & $1.01(0.77)$ & $0.06(0.05)$ \\
Affect & $1.01(0.31)$ & $1.75(1.05)$ & $1.07(0.99)$ \\
Cause & $2.14(1.11)$ & $1.93(0.7)$ & $2.18(1.23)$ \\
Social & $2.62(0.92)$ & $3.42(1.01)$ & $2.60(2.09)$ \\
Family & $0.51(0.40)$ & $0.62(0.31)$ & $0.65(0.61)$ \\
Friends & $0.34(0.11)$ & $0.36(0.14)$ & $0.09(0.07)$ \\
Power & $1.08(0.77)$ & $0.51(0.32)$ & $0.93(0.13)$ \\
Focus present & $1.54(1.12)$ & $1.66(1.14)$ & $2.93(1.21)$ \\
Focus past & $1.01(0.07)$ & $1.52(1.23)$ & $1.27(1.09)$ \\
Focus future & $0.36(0.12)$ & $0.27(0.11)$ & $0.35(0.23)$ \\
\hline
\end{tabular}

Note: FG 1 - focus group of individuals with a low level of retirement preparedness, FG 2 - focus group of individuals with a medium level of retirement preparedness, FG 3 - focus group of individuals with a high level of retirement preparedness

\section{I and Verbal Tense Categories}

Evidence consistently suggests that individuals with physical and emotional pain focusing on themselves more frequently use first-person singular pronouns (Zasiekin et al., 2018). However, other research pointed out that individual selfreference is associated with positive view of themselves as active subjects (Zasiekina \& Mahdysiuk, 2018). In addition, these findings suggest that more selfreferences were more present in positive narratives compared with negative narratives. The most obvious finding to emerge from analysis in the current study is that self-reference was more present in FG 2. The interviews in FG 2 highlight the participants' intentions to harmonize relationship between professional and personal life, taking much efforts in this direction. One unanticipated finding was that interviews in FG 3 indicate less self-reference compared with FG 2. A possible explanation for this might be that individuals with a high level of preparedness for retirement demonstrate their key intentions only in their personal life, notably family relationships, hobby, friends, omitting their current interests in professional life. On the contrary, individuals from FG1 talked mostly about their career, focusing exclusively on professional goals and activities. In addition, individuals from FG 3 have the most reference to the present moment, which is associated, according to our previous findings (Zasiekina \& Mahdysiuk, 2018), with wellbeing, while individuals with FG 1 demonstrate the lest references to the present, focusing mostly on their past life episodes, aligned with professional growth. In addition, findings of recent research showed that individuals used more present and future tense verbs in the positive narratives compared with more past tense verbs in negative narratives (Tausczik \& Pennebaker, 2010). 
(FG 1) I remember coming to Vorokomle in 1975. The first day on September 15 to work. And immediately went to work. Training began on September 1. It was difficult at first, because the students were not familiar, the area was unfamiliar, but I eventually got used to it. I came to work in the 2nd grade, and then in 2 years to work. Then there were 4 classes, in 2 years I had 1 class. And so every year, and so I had worked for 40 years, finishing 4th grade, and then from 1st grade started again.

(FG 2) I really love my job. In 1989 I graduated from the Lutsk Pedagogical Institute and began my professional career in the neighboring village of Vyderta. After some time I went to work in my native school and had worked as a teacher for some time. I had worked as a senior teacher for educational work for 9 years and resigned due to illness. I love my job very much. I love children very much, I gladly go to school. I feel that students really need me, I share my knowledge with them, we travel to the world of beautiful literature, we get acquainted with different works, we learn to live, to think. But I can't say that work has the biggest place in my life. I am finishing my professional activity now, then of course there are plans, there are hobbies. I really like reading fiction, so I will have plenty of time to do my favorite thing. I want to immerse myself in the world of beauty, to read those works that I have not read yet, due to lack of time. And, of course, I will be proud of my students! (FG 3) Now I am thinking about it. Although I'm used to working. Work is not the main thing in life, it is an opportunity to earn money for life. There are things that are more important. There will be more time to read literature. I want to travel a lot. I don't have a dacha, I don't like it. I have many friends, we communicate especially closely with classmates. We often meet. When someone finds a wonderful poem, we immediately gather and listen. And it doesn't matter how many children or grandchildren you have.

\section{Positive Emotions and Affects Categories}

As can be seen from the table above is that categories of positive emotions and affect were more present in FG 2 compared with FG1 and FG3. The interviews in FG 2 highlight the participants' positive attitudes to professional and personal life, including emotional states of happiness, joys and satisfaction with their personal and professional achievements. One unexpected finding was that interviews in FG 1 indicate more references to positive emotions compared with FG 3. A possible explanation for this might be that individuals with a low level of preparedness for retirement demonstrate their highly positive attitude and deep involvement into professional life, which is, on one hand, provide basis for their professional wellbeing, however, on the other hand, caused a low preparedness for retirement. As Tausczik and Pennebaker (2010) argue the degree to which people express emotion, how they express emotion, and the valence of that emotion can tell us how people are experiencing the world, in our study professional and personal life ( $\mathrm{p}$. 32) 
(FG 1) Well, I can't say I'm sorry about anything. Most of all I have school and love for children. I love them and I live by it. Now working as a deputy, I can say that I miss those children with whom I worked before, because I had to devote more time to such managerial work, managerial position. I felt more comfortable in class. For me, it's a lifetime.

(FG 2) I love work. I want to change the world for the better, to raise good, smart citizens of our state. I especially like to see the interested eyes of my students. At the moment I am a class teacher, so I love it when my students come to my house and ask for advice. But great joy and happiness to be at home, to enjoy the summer, family and friends.

(FG 3) What worries me most now is the question of people who have no relatives or children and are very lonely. I could help because I can listen, and that's very important for older people. Perhaps such organizations or clubs, if they were created at monasteries or churches, I could work there and benefit. In this case, I would definitely be useful to people. It seems to me that this idea and activity is very necessary and interesting.

\section{Cause, Social Relationship, Friends and Power Categories}

Tausczik and Pennebaker (2010) differentiate two subgroups of causal words, notably because, effect, hence, and insight words, particularly think, know, consider, which express cognitive processes of reappraisal. Moreover, a frequent use of causal words is marker of enhancing health, well-being and quality of life. The most obvious finding to emerge from analysis in the current study is that causal words were more present in FG 3 compared with FG 1 and FG 2. The interviews in FG 3 highlight the participants' reappraisal of sense of their life, the role of career as only a part of their life. We assume that reappraisal of professional career in personal life and revealing other senses in life might improve physical and mental being of individuals with a high level of preparedness for retirement. The interviews in FG 3 highlight the participants' attachment to their family, while interviews in FG 2 highlight the participants' close interaction with friends and other social settings. A possible explanation for this might be that individuals with a high level of preparedness for retirement demonstrate a deep involvement into family relationship as a preliminary stage for forthcoming retirement. Participants with a low level of preparedness for retirement are at the stage of reappraisal their career in their life, preserving active relationship with friends, collogues and other people in different social setting. The low reference to category family in FG 1 has been compensated the highest frequency of category power. A possible explanation for this might be that individuals with a low level of preparedness for retirement demonstrate a great involvement in career and professional growth.

(FG 1) As a principal, I can say that the microclimate in our team is very good. Everyone empathizes with each other, helps each other. Even if a 
district seminar is being prepared, it is not one person involved, but the whole team. Cooperation, always in our team, is a creative cooperation. As a leader, I do not care about the age of the teachers of our team. I insist that all seniors share their experience with the younger ones, and the younger teachers go and ask for advice from their senior colleagues. And we have a very close cooperation with the education department of the city and Oblast, which always supports the school administration.

(FG 2) Work... I love work. But it does not play a vital role in my life, no. My family is always in the forefront, although judging by the opinions of my colleagues, I am a very good teacher, I give good lessons. For example, every day I diligently prepare for those lessons, colleagues and children love me very much. And my friends have always meant a lot to me in my life.

(FG 3) I'm happy with everything. The only thing I regret is that I paid little attention to my family, my daughter's upbringing. Family is the most important thing for me now. I will dedicate myself completely to my family.

\section{Conclusion}

The purpose of the current study was to determine constructing meaning of retirement in individuals with different levels of retirement preparedness and examines the main difficulties in preretirement period, expressed verbally in retirement planning interviews. This study has shown that individuals with different levels of retirement preparedness have different meaning of retirement. Individuals with a low level of preparedness for retirement construct meaning mostly in categories of profession, carrier, social interaction and power in professional settings. Individuals with a medium level of preparedness for retirement construct meaning in terms of both personal and professional life, close interaction with colleges, family and friends. Therefore, they use categories of social interaction, present moment, and first person pronoun marking themselves as a source of high activity. Individuals with a high level of preparedness for retirement focus predominantly on family and family relationship. Therefore, they have a high reference to category of family. Interestingly, the highest percentage of categories of affect and positive emotions were observed in the group with a medium level of preparedness, whereas the highest indices of categories cause, focus on present, and family were captured in the group with a high level of preparedness. Taken together, these results suggest that the high level of retirement preparedness is associated with active cognitive reappraisal of retirement as a period of family activities. One of the more significant findings to emerge from this study is that the main difficulty of the individuals with a low level of preparedness for retirement is a low adjustment to postretirement period and drawing attention exclusively on the career and professional growth. This study has provided a deeper insight into significance of preparedness for retirement, which could be a planned supporting policy for workers in preretirement period. More broadly, research is needed to 
determine association of preparedness for retirement and retirees' well-being. The findings of this study have a number of important implications for future practice, providing foundations for psychological support for individuals with a low level of preparedness for retirement.

\section{References (translated and transliterated)}

Astuti, D. (2020). Readiness in retirement life. SHS Web of Conferences 76, 01004. https://doi.org/10.1051/shsconf/20207601004

De los Santos, J. A. A., Labrague, L. J., \& Milla, N. E. (2019). Happiness and retirement readiness among pre-retiring employees: a cross-sectional study. Ageing International, 45, 85-98. https://doi.org/10.1007/s12126-019-09351-z

Park, S. M. (2017). The gendered impact of the National Pension Scheme on late-life economic well-being: evidence from the Korean retirement and income study. Quality in Ageing and Older Adults, 19(1), 3-13. https://doi.org/10.1108/QAOA-09-2016-0039

Osborne, J. W. (2012). Psychological effects of the transition to retirement. Canadian Journal of Counselling and Psychotherapy, 46(1), 45-58.

Tausczik, Y. R., \& Pennebaker, J. W. (2010). The psychological meaning of words: LIWC and computerized text analysis methods. Journal of Language and Social Psychology, 29(1), 24-54. https://doi.org/10.1177/0261927X09351676

Victor, C. R. (2013). Old age in modern society: A textbook of social gerontology. Springer.

Wang, M., Olson, D. A., \& Shultz, K. S. (2012). Mid and late career issues: An integrative perspective. Routledge.

Wang, M., \& Shi, J. (2014). Psychological research on retirement. Annual Review of Psychology, 65, 209-233. https://doi.org/10.1146/annurev-psych-010213-115131

Wang, M., \& Shultz, K. S. (2010). Employee retirement: A review and recommendations for future investigation. Journal of Management, 36(1), 172206. https://doi.org/10.1177\%2F0149206309347957

Zasiekin, S., Bezuglova, N., Hapon, A., Matiushenko, V., Podolska, O., \& Zubchuk, D. (2018). Psycholinguistic aspects of translating LIWC dictionary. East European Journal of Psycholinguistics, 5(1), 111-118. https://doi.org/10.29038/eejpl.2018.5.1.zas

Zasiekina, L., Mahdysiuk, L. (2018). Psykholohichna hotovnist osobystosti do vykhodu na pensiyu [Individual Psychological Preparedness for Retirement]. Lutsk: Ivaniuk. 